\title{
Spontaneous Arachnoid Cyst Rupture With Subdural Hygroma in a Previously Asymptomatic Man: Case Report
}

\author{
Öncesinde Asemptomatik Olan Subdural Higroma Ile Seyreden Spontan Araknoid Kist Rüptürü: Olgu Sunumu \\ Ercan Nalbant ${ }^{1 \odot}$, Mehmet Altuntaş ${ }^{\odot} \odot$
}

\section{ABSTRACT}

Aim: Spontaneous rupture of an arachnoid cyst resulting in a subdural hygroma is an infrequent event. We report an adult patient who had no previous neuroimaging and had acute onset headache, dizziness, and nausea unrelated to trauma.

Case: A 67-year-old male patient was brought to the emergency service complaints of sudden onset of dizziness, headache, and vomiting while working in the garden. He described ongoing nausea and headache localized to the frontal region. Brain CT imaging was planned for the patient whose nausea and dizziness worsened while his symptomatic treatment continued. In the brain CT, a large hypodense extracerebral collection was detected in the area starting from the middle fossa in the right cerebral hemisphere and extending to the convexity level in the frontoparietal region. The patient was consulted in the neurosurgery unit. Surgical intervention was not considered, and the patient was admitted to the neurosurgery service for treatment. Due to the asymptomatic course in the service follow-ups, he was discharged with outpatient clinic control recommendations.

Conclusion: This case illustrates the importance of recognizing the possibility of spontaneous rupture of an arachnoid cyst. This phenomenon should be considered as a differential diagnosis in patients without head trauma. Although it is rare, being aware of such a case is helpful in preventing possible bad outcomes.

Keywords: Arachnoid cyst, subdural hygroma, brain surgery
Öz

Amaç: Araknoid kistin subdural higroma ile sonuçlanan spontan rüptürü nadir görülen bir olaydır. Daha önce nörogörüntüleme yapılmamış ve travmaya bağlı olmayan akut başlangıçı baş ağrısı, baş dönmesi ve mide bulantısı olan yetişkin bir hastayı sunuyoruz.

Olgu: 67 yaşında erkek hasta bahçede çalışırken aniden başlayan baş dönmesi, baş ağrısı ve kusma şikayetleriyle acil servise getirildi. Frontal bölgeye lokalize devam eden bulantı ve baş ağrısı tarif etti. Semptomatik tedavisi devam ederken bulantı ve baş dönmesi artan hastaya beyin BT görüntüleme planlandı. Beyin BT'sinde sağ serebral hemisferde orta fossadan başlayıp frontoparietal bölgede konveksite seviyesine kadar uzanan alanda geniş hipodens ekstraserebral koleksiyon saptandı. Hasta beyin cerrahisi ünitesinde konsülte edildi. Cerrahi müdahale düşünülmedi ve hasta tedavi için beyin cerrahisi servisine yatırıldı. Servis takiplerindeki asemptomatik seyir nedeniyle poliklinik kontrol önerileri ile taburcu edildi.

Sonuç: Bu vaka, araknoid kistin spontan rüptürü olasılığını bilmenin önemini göstermektedir. Bu fenomen kafa travması olmayan hastalarda ayırıcı tanı olarak düşünülmelidir. Nadir de olsa böyle bir durumun farkında olmak olası kötü sonuçların önlenmesinde yardımcı olur.

Anahtar Kelimeler: Araknoid kist, subdural higroma, beyin cerrahisi

${ }^{1}$ Department of Emergency Medicine, Rize State Hospital, Rize-Turkey.

2 Department of Emergency Medicine, Recep Tayyip Erdoğan University Faculty of Medicine, Rize-Turkey

Corresponding Author: Ercan Nalbant, MD Address: Department of Emergency Medicine, Rize State Hospital, Rize-Turkey.Phone: +905428291398 e-mail 


\section{Introduction}

Arachnoid cysts, which are usually detected incidentally on intracranial imaging, are associated with a benign prognosis in asymptomatic patients (1). Subdural hematoma, intracystic hemorrhage, and the development of subdural hygroma are rare complications that may occur following head trauma (2-5). Subdural hygroma due to spontaneous arachnoid cyst rupture is extremely rare (6).

\section{Case Report}

A 67-year-old male patient was brought to the emergency service complaints of sudden onset of dizziness, headache, and vomiting while working in the garden. The patient, who had no previous history of chronic disease, stated that he had such a severe headache for the first time. According to the history taken from him, he did not have a fever recently and did not experience any severe head trauma.

\section{Clinical Findings}

Although the patient's vital parameters were stable, his Glasgow Coma Score was taken over as 15. In the emergency department, the patient's blood pressure was 130/80 $\mathrm{mm} / \mathrm{Hg}$, pulse was $75 / \mathrm{min}$, saturation was $99 \%$, and blood glucose was $95 \mathrm{mg} / \mathrm{dl}$. In the detailed neurological examination of the conscious patient, both upper and lower extremity strength examinations were $5 / 5$, nuchal rigidity and pathological reflex were absent. Light reflexes were normal.

\section{Diagnostic Evaluation}

He described ongoing nausea and headache localized to the frontal region. There was no pathology in the patient's blood tests, liver and kidney function tests, electrolyte values and hemogram examination. Because the patient was at an advanced age and had the most severe headache in his life, symptomatic treatment was started and Brain CT imaging was planned for the patient without delay. In the brain CT, a large hypodense extracerebral collection was detected in the area starting from the middle fossa in the right cerebral hemisphere and extending to the convexity level in the frontoparietal region (Figure 1).

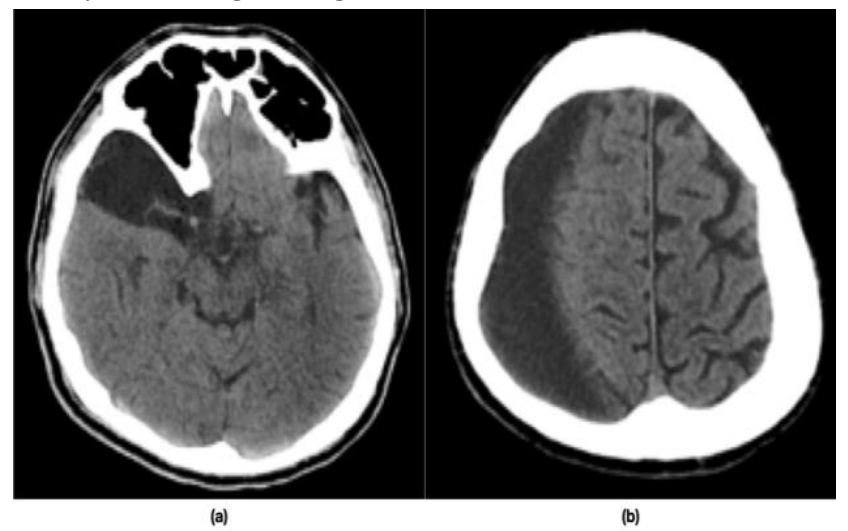

Figure 1. CT brain axial image (a) shows an arachnoid cyst in the right temporal region. Axia image (b) shows right frontoparietal crescent-shaped subdural fluid collections.
In the MRI taken for detailed examination, the appearance thought to belong to an isointense arachnoid cyst with CSF is observed in all sequences, with dimensions of $84 \times 65 \mathrm{~mm}$ originating predominantly from the anterior temporal fossa, adjacent to the temporal and parietal lobes on the right. In addition, a subdural effusion, predominantly isointense with CSF, was observed on the right, extending along with the parietal convexity location in the pericerebral CSF space and reaching $119 \times 21 \mathrm{~mm}$ dimensions, showing similar signal characteristics (Figure 2).

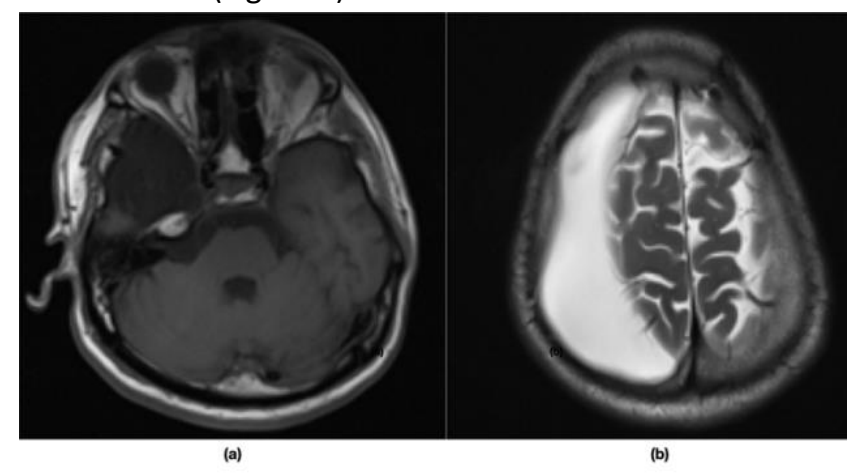

Figure 1. MRI brain axial T1 image (a) showing an extra-axial fluid signal intensity lesion in the right temporal region. Axial $\mathrm{T} 2$ weighted image shows right frontoparietal crescent-shaped subdural fluid collections.

\section{Therapeutic Intervention}

Antiemetic and analgesics were administered to the patient in the emergency room for symptomatic treatment of his complaints. The patient was consulted in the neurosurgery unit. Surgical intervention was not considered, and the patient was admitted to the neurosurgery service for treatment. Due to the asymptomatic course in the service follow-ups, he was discharged with outpatient clinic control recommendations.

Written informed consent was obtained from the patient for publication of this case report and any accompanying images.

\section{Discussion}

Arachnoid cysts become symptomatic when they grow in size or rupture (7). The most frequent presenting symptom associated with arachnoid cysts is headache (3). It is seen two times more in men than in women (1). Most remain asymptomatic and surgical intervention is only planned for cysts that have neurologic symptoms due to mass effect or cause symptoms of hydrocephalus. It is not fully understood why the cysts grow, and it is not possible to predict in which cysts this will occur (8). Younger patients are more likely to be symptomatic (9). The arachnoid cyst consists of a thin membrane. It has been suggested that enlargement of the cyst is due to the production of cerebrospinal fluid by the cyst walls (3). If the cyst enlarges, it may cause symptoms of increased intracranial pressure, nausea, and vomiting, focal neurological deficits, or hydrocephalus (10). A series of adults with arachnoid cysts showed that $2.5 \%$ of the cysts increased in size, and $0.5 \%$ developed symptoms due to the 
Spontaneous Arachnoid Cyst Rupture

enlarging cyst (1). It is recognized that when they cause neurological symptoms, they must be surgically decompressed via endoscopic or microsurgical fenestration or cysto-peritoneal shunt (11). Increased intracranial pressure and valsalva maneuver are other possible causes of cyst rupture and hygroma. The most common finding of arachnoid cyst rupture on imaging is a collection in the subdural space (7).

In our case, although there was no previous brain imaging, an extra-axial cystic lesion and a subdural collection with the same signal were observed in its vicinity. Given the absence of a history of head trauma and imaging results, it was concluded that these findings represent spontaneous rupture of an arachnoid cyst resulting in a subdural hygroma.

\section{Conclusion}

This case illustrates the importance of recognizing the possibility of spontaneous rupture of an arachnoid cyst. This phenomenon should be considered as a differential diagnosis in patients without head trauma. Although it is rare, being aware of such a case is helpful in preventing possible bad outcomes.

Conflict of Interest: No conflict of interest was declared by the authors.

Financial Disclosure: No financial disclosure was declared by the authors.

Authors Contribution: EN, MA contributed equally to designing the study and preparation of the manuscript.

Informed Consent Statement: Written informed consent was obtained from the patient for publication of this case report and any accompanying images. A copy of the written consent is available for review in this journal.

\section{References}

1. Al-Holou WN, Terman S, Kilburg C,et al. Prevalence And Natural History Of Arachnoid Cysts in Adults. J Neurosurg. 2013 Feb;118(2):222-31. doi: 10.3171/2012.10.JNS12548. Epub 2012 Nov 9.

2. Rajesh A, Bramhaprasa, V, Purohit AK. Traumatic Rupture Of Arachnoid Cyst With Subdural Hygroma. J Pediatr Neurosci. 2012 Jan;7(1):33-5. doi: 10.4103/1817-1745.97620.

3. Gosalakkal JA. Intracranial Arachnoid Cysts in Children: A Review Of Pathogenesis, Clinical Features, And Management. Pediatr Neurol. 2002 Feb;26(2):93-8. doi: 10.1016/s0887-8994(01)00329-0.

4. Adin ME, Yıldız MS, Deniz MA, et al. Arachnoid Cysts With Spontaneous Intracystic Hemorrhage and Associated Subdural Hematoma: Report Of Management And Follow-Up Of 2 Cases. Radiol Case Rep. 2017 Dec 29;13(2):516-521. doi: 10.1016/j.radcr.2017.12.006.

5. Khilji, MF, Jeswani NL, Hamid RS, et al. Spontaneous Arachnoid Cyst Rupture With Subdural Hygroma in a Child. Case Rep Emerg Med. 2016;2016:6964713. doi: 10.1155/2016/6964713. Epub 2016 Feb 18.

6. Bora A, Yokuş A, Batur A, et al. Spontaneous Rupture Of The Middle Fossa Arachnoid Cyst Into The Subdural Space: Case Report. Pol J Radiol. 2015 Jun 22;80:324-7. doi: 10.12659/PJR.893928.
7. Balestrino A, Piatelli G, Consales A, et Al. Spontaneous Rupture of Middle Fossa Arachnoid Cysts: Surgical Series From a Single Center Pediatric Hospital and Literature Review. Childs Nerv Syst. 2020 Nov;36(11):2789-2799. doi: 10.1007/s00381-020-04560-3.

8. Hall S, Smedley A, Sparrow O, et al. Natural History of intracranial Arachnoid Cysts. World Neurosurg. 2019 Jun;126:e1315-e1320. doi: 10.1016/j.wneu.2019.03.087.

9. Lee JY, Kim JW, Phi JH, et Al. Enlarging Arachnoid Cyst: A False Alarm for Infants. Childs Nerv Syst. 2012 Aug;28(8):1203-11. doi: 10.1007/s00381-012-1722-z.

10. Schulz, M, Kimura T, Akiyama O, et al. Endoscopic And Microsurgical Treatment of Sylvian Fissure Arachnoid Cysts-Clinical And Radiological Outcome. World Neurosurg. 2015 Aug;84(2):327-36. doi: 10.1016/j.wneu.2015.03.026.

11. Chen Y, Fang HJ, Li ZF, et Al. Treatment of Middle Cranial Fossa Arachnoid Cysts: A Systematic Review And Meta-Analysis. World Neurosurg. 2016 Aug;92:480-490.e2. doi: 10.1016/j.wneu.2016.06.046. 